\title{
Expeditious production of concentrated glucose-rich hydrolysate from sugarcane bagasse and its fermentation to lactic acid with high productivity
}

\author{
Pratibha Baral ${ }^{1}$, Anushka Pundir ${ }^{1}$, Vinod Kumar ${ }^{2}$, Akhilesh K. Kurmi ${ }^{1}$ and Deepti \\ Agrawal $^{1 *}$ \\ ${ }^{1}$ Biochemistry and Biotechnology Area, Material Resource Efficiency Division, CSIR- Indian \\ Institute of Petroleum, Mohkampur, Dehradun-248005, India \\ ${ }^{2}$ Centre for Climate and Environmental Protection, School of Water, Energy and \\ Environment, Cranfield University, Cranfield MK43 0AL, UK
}

*Corresponding author: Tel: +91-135-2525763; Email address: deepti@iip.res.in;

Orcid ID: 0000-0002-6224-3580

Declarations of interest: none

\begin{abstract}
Sugarcane bagasse (SCB) is anticipated to emerge as a potential threat to waste management in India on account of cheap surplus energy options and lower incentives through its cogeneration. Through biotechnological intervention, the efficient utilization of SCB is seen as an opportunity. The present study aimed towards expeditious production of concentrated glucose-rich hydrolysate from SCB. Alkali pretreated biomass was chosen for hydrolysis with a new generation cellulase cocktail, Cellic CTec2 dosed at $25 \mathrm{mg} \mathrm{g}^{-1}$ glucan content. A two-step $(9 \%+9 \%)$ substrate feeding strategy was adopted with a gap of an hour, and saccharification was terminated in three different ways. Irrespective of the methods employed for termination, $\sim 84.5 \%$ cellulose was hydrolyzed releasing $\geq 100 \mathrm{~g} \mathrm{~L}^{-1}$ glucose from $18 \%$ biomass. Direct use of glucose-rich filtrates yielded $69.2 \pm 2.5 \mathrm{~g} \mathrm{~L}^{-1}$ of L (+) lactic acid (LA) using thermophilic Bacillus coagulans NCIM 5648. The best-attained glucose and LA productivities during separate hydrolysis and fermentation (SHF) in the present study were 5.27 and $2.88 \mathrm{~g} \mathrm{~L}^{-1} \mathrm{~h}^{-1}$, respectively. A green and sustainable process is demonstrated for the production of industrially relevant sugars from SCB at high productivity and its valorization to bio-based LA.
\end{abstract}

Keywords: Cellic CTec2; alkali pretreated sugarcane bagasse; high-solids saccharification; glucose-rich filtrate; productivity; lactic acid 


\section{Highlights}

- Saccharification of $18 \%$ alkali pretreated sugarcane bagasse attempted

- Three strategies adopted for termination of the batch hydrolysis

- Cellic CTec2 released $\geq 100 \mathrm{~g} \mathrm{~L}^{-1}$ glucose in $24 \mathrm{~h}$ with $5.27 \mathrm{~g} \mathrm{~L}^{-1} \mathrm{~h}^{-1}$ productivity

- B. coagulans mediated fermentation yielded $69.2 \pm 2.5 \mathrm{~g} \mathrm{~L}^{-1} \mathrm{~L}(+)$ lactic acid 


\section{Introduction}

Disruptive technological innovations in sustainable and profitable management of agricultural wastes may be highly rewarding for the emerging economies like India. Besides being cheap, abundant and easily available these lignocellulosic biomasses (LCB's) are the natural source of renewable carbon. Successful transformation of the embedded carbon in these feedstocks into versatile products such as bio-based chemicals, biofuels, bio-power etc. can benefit any nation. Besides contributing towards the self-reliance and energy security, such technologies can generate new employment opportunities, foster the rural economy and curtail down the green-house gas (GHG) emissions as well (Guragain et al., 2016; Wenger and Stern, 2019; Vera et al., 2020). Particularly cellulose, which represents a significant fraction of LCB, is an insoluble structural homo-polysaccharide and inexhaustible source of glucose. However, for industrial feasibility, the glucose release from cellulose in "concentrated form" is highly desirable. Once the sugar syrup is obtained, several products can be synthesized at high-titres, using various chemical and biotechnological routes. There are multiple advantages of getting concentrated input (sugar) and output carbon products (fuels, chemicals etc), as they reduce the capital and operational expenditure (CAPEX and OPEX) involved in their production, downstream processing, waste disposal etc. (da Silva et al., 2020).

Presently in India, the annual production of sugarcane bagasse (SCB) from various sugar industries and distilleries account for $\sim 80$ million metric tonnes. This inexpensive and potential agricultural waste is anticipated to loom as the biggest problem in the next five years by the "Sugar Technologists Association of India" (STAI). Earlier, the industries used SCB for cogeneration. But easily accessible and cheaper surplus energy options such as hydro, thermal and solar etc. has reduced its usage for the production of heat and electricity (Patel., 2019). Hence the industries are exploring lucrative options for efficient utilization of SCB where commercially viable bio-based products can be manufactured. Profit margin of any product is generally governed by its applications, market size, production costs, consumer and industrial demand etc. (Guragain et al., 2016; Wenger and Stern, 2019). Thus, there is tremendous scope for the researchers and technocrats to leverage upon promising biorefining processes targeting specific bio-based products. By coupling techno-economic analysis (TEA) with life cycle assessment (LCA), these processes can be further vetted and can be easily integrated with $500+$ operating sugar mills in India as per the data of Indian Sugar Mills Association (ISMA) (https://www.indiansugar.com/Statics.aspx). 
One of the straightforward strategies for attaining industrially relevant sugar yields from SCB could be its high-solids enzymatic saccharification (HSES). In this green process, there is no availability of free water on the commencement of the hydrolysis (Da Silva et al., 2020). Several variable and inter-related factors impede the process of HSES. Process conditions, namely water constraints, mass transfer limitations and rheological characteristics of the whole slurry are the primary culprits. But intrinsic properties of enzymes such as inhibition due to lignin, water-soluble and insoluble degradation products, oligomeric and monomeric sugars also impact biomass liquefaction (Da Silva et al., 2020; Fockink et al., 2017; Liu et al., 2020).

State of the art suggests that most of the batch HSES studies with different types of pretreated LCB's are carried out for a minimum period of $72 \mathrm{~h}$ which may further extend up to $144 \mathrm{~h}$, as reviewed earlier (Modenbach and Nokes, 2013; Chen and Liu, 2016). The constraint of a single feeding substrate regime is overcome by adopting fed-batch strategies. But in such cases, to ensure complete hydrolysis of LCB, time is often stretched, as demonstrated by various co-workers (Gao et al., 2014; Mukasekuru et al., 2018). One of the noteworthy advancement to improve the efficacy of HSES has been the use of new generation cellulase cocktails. These unique cocktails are less prone to inhibitors. Further, they have an arsenal of accessory hydrolytic and non-hydrolytic enzymes such as xylanase, $\beta$-glucosidase, swollenin, cellobiose dehydrogenase (CDH), lytic polysaccharide monooxygenase (LPMO), which synergistically enhance cellulose hydrolysis (Ekwe et al., 2013; Lopez et al., 2018; da Silva et al., 2020).

Taking into account the future opportunities and acknowledging the challenges with HSES, an investigation was undertaken where hydrolysis of $18 \%$ partially delignified SCB was carried out. The study targeted the release of a minimum $10 \%$ glucose at high productivity from its cellulosic fraction using Cellic CTec2, a known new generation commercial cellulase (Cannella and Jørgensen., 2013). In our earlier study, substrate loading beyond $12.5 \%$ drastically reduced the glucose productivity and led to incomplete cellulose hydrolysis during shorter incubation time (Nalawade et al., 2020). Therefore to overcome the drawback of batch hydrolysis arising due to poor mixing, in the present study a two-stage $(9 \%+9 \%)$ substrate feeding strategy was adopted within a gap of one hour. Later, the concentrated glucose-rich hydrolysate was directly valorized to L (+) lactic acid (LA). Separate hydrolysis and fermentation (SHF) with thermophilic Bacillus coagulans NCIM 5648 was inspired by the findings of Müller et al. (2017). They suggested that Cellic CTec2 outperformed in terms 
of LA productivity under this condition as against simultaneous saccharification and fermentation (SSF) due to the absence of competition from microbes for dissolved oxygen (2017).

LA was chosen as the targeted product as presently the commercial production of LA is dominated via fermentation (Tarraran and Mazzoli, 2018). Moreover, this versatile platform chemical finds numerous applications in various sectors such as food and beverages, chemical industry, cosmetics, pharmaceuticals, textiles etc. with poly-lactic acid (PLA) being the most demanding biodegradable polymer product flourishing its market demand ( CubasCano et al., 2018). More recently Rosales-Calderon and Arantes have reviewed LA as one of the most promising commodity chemical to reduce the cost of cellulosic ethanol production (2019) whereas Mandegari et al., have proposed LA to be more advantageous the cellulosic ethanol in terms of LCA (2017).

\section{Materials and methods}

\subsection{Raw Material and Enzyme}

Raw SCB and Cellic ${ }^{\circledR}$ CTec2 were kindly gifted by Dhampur Sugar Mills, India and Novozymes A/S, Denmark respectively. Cellic CTec2 contained 93.89 $\pm 0.99 \mathrm{mg}$ BSA equivalents protein $\mathrm{g}^{-1}$ enzyme as assayed by the method of Bradford (1976). The enzyme activity in terms of filter paper units (FPU) was found to be $125.8 \pm 2.6 \mathrm{IU} / \mathrm{g}$, measured as per IUPAC protocol (Ghosh, 1987).

\subsection{Alkali pretreatment and compositional analysis}

Alkali pretreatment was conducted as per the method described previously with slight modifications (Nalawade et al., 2020). The previous study revealed when the water bath was set at $80^{\circ} \mathrm{C}$ the difference between the water bath and the slurry temperature was $\sim 15^{\circ} \mathrm{C}$. Hence $5 \%$ raw SCB was suspended in $0.5 \mathrm{M} \mathrm{NaOH}$, and the beaker was placed only when the water bath reached at $95^{\circ} \mathrm{C}$. To ensure uniform mixing, a homogenizer (Remi Motors RQ124A; Mumbai, India) set at $200 \mathrm{rpm}$ was used and when the slurry temperature reached $76 \pm 2{ }^{\circ} \mathrm{C}$, the delignification of the SCB was allowed for $120 \mathrm{~min}$. After pretreatment, the solids were separated by filtering and then washed until a neutral $\mathrm{pH}$ was obtained. The compositional analysis as per the procedure of National Renewable Energy Laboratory (NREL) revealed that alkali pretreated biomass contained $63.74 \pm 1.38 \%$ cellulose, $17.05 \pm$ $0.42 \%$ xylan, $12.19 \pm 0.27 \%$ acid-insoluble lignin (AISL), $1.28 \pm 0.01 \%$ acid-soluble lignin (ASL) and $2.93 \pm 0.13 \%$ ash (Sluiter et al., 2012; Sluiter et al., 2008). This biomass served as the starting feedstock for HSES. 


\subsection{HSES of alkali pretreated SCB}

Saccharification study was carried out at $18 \%(\mathrm{w} / \mathrm{w})$ substrate loading in a non-buffered medium ( $\mathrm{pH} 4.5$ ) containing PEG 6000 (0.2g/g AISL content) placed in an incubator shaker set at $50^{\circ} \mathrm{C}, 180 \mathrm{rpm}$ as described previously (Baral et al., 2020). A two-step substrate feeding strategy $(9 \%+9 \%)$ within a gap of one hour was adopted to mitigate the problem of poor mixing as observed previously (Nalawade et al., 2020).

Cellulose hydrolysis was expedited by adding Cellic CTec2 (25 mg protein $\mathrm{g}^{-1}$ glucan content) in bulk at the very start of the hydrolysis, corresponding to $18 \%$ substrate. Time course profile was studied during hydrolysis by intermittent removal of flasks to decipher the duration where it attained product saturation. SCB hydrolysis was terminated in three different ways, as shown in Figure 1.

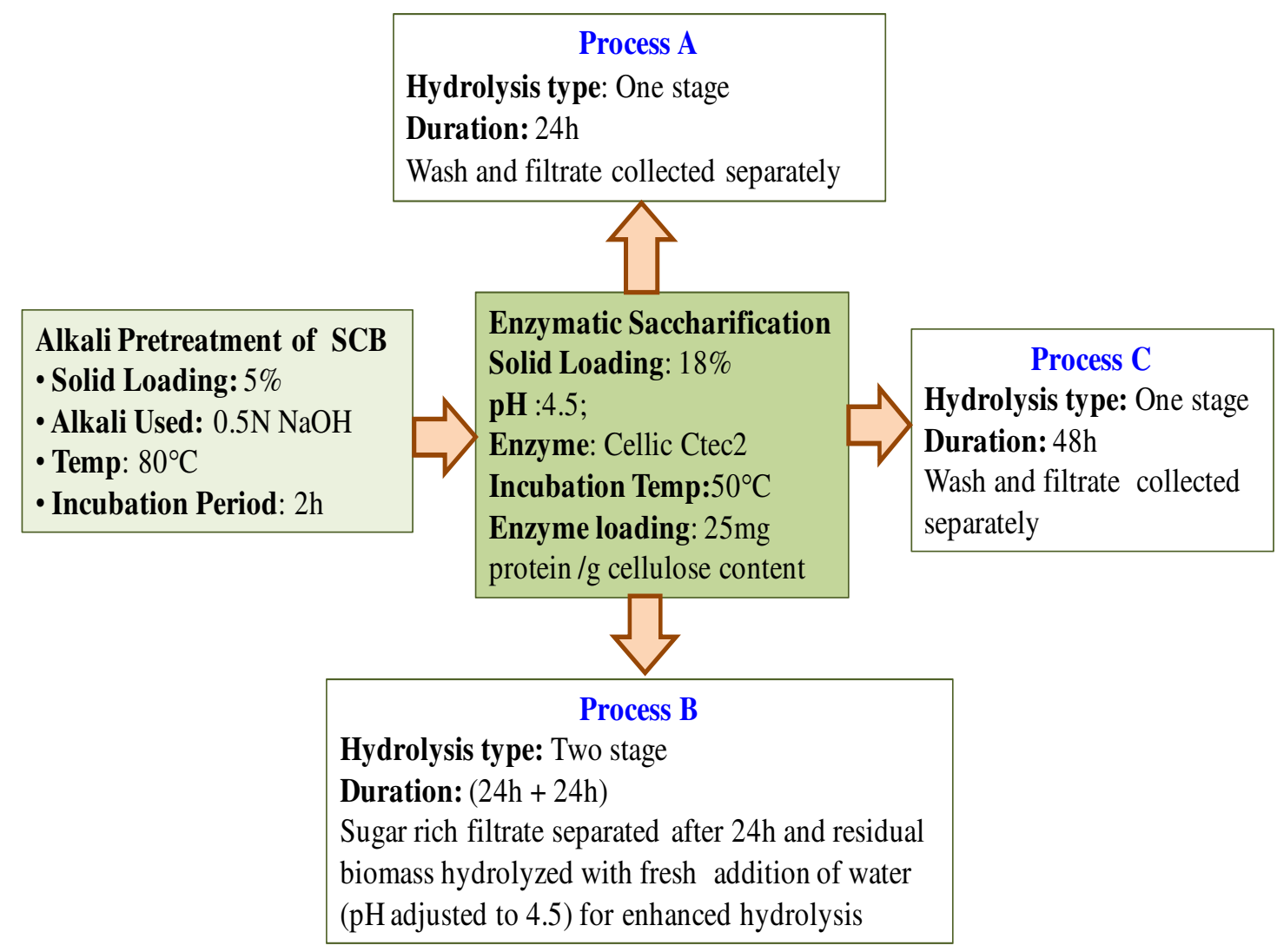

Fig.1 Schematics of terminating Cellic CTec2 aided saccharification conducted with alkali pretreated

In Process A and C, batch hydrolysis was conducted for 24 and $48 \mathrm{~h}$ respectively, whereas in Process B, discontinuous batch hydrolysis was attempted. After $24 \mathrm{~h}$ hydrolysis, the reaction was arrested, and sugar-rich filtrate was removed and water washed. Based on the fermentable sugars obtained in the filtrate and wash fraction, the amount of hydrolysed 
biomass was calculated and second round of hydrolysis was carried out for next $24 \mathrm{~h}$ by adding appropriate amount of acidified water $(\mathrm{pH} 4.5)$ in residual biomass. Thus in discontinuous mode also $18 \%$ solids concentration was maintained and hydrolytic potential of Cellic CTec2 adsorbed to the biomass was explored.

When hydrolysis was completed, the residual solid fraction was separated from the saccharified broth by centrifugation at $5752 \mathrm{~g}$ (equivalent to $7000 \mathrm{rpm}$ ) for $10 \mathrm{~min}$ at $4^{\circ} \mathrm{C}$. This concentrated sugar-rich solution was termed as "filtrate". Washing step was found inevitable to recover the adhered sugars from the biomass in our earlier study (Nalawade et al., 2020. Therefore, the residual biomass was water washed (equivalent to $50 \%$ filtrate volume) and said sugar solution was termed as "wash".

Filtrate and wash fractions were subjected to high performance liquid chromatography (HPLC) for analysis of all hydrolysed products released from alkali pretreated SCB during saccharification.

Before proceeding for LA fermentation, enzyme activity was thermally inactivated in the glucose-rich filtrates and washes. The coagulated protein was removed by centrifugation, and $\mathrm{pH}$ was neutralized using $25 \%$ liquor ammonia. They were stored at $4^{\circ} \mathrm{C}$ until used for LA fermentation. The main fermentation studies were carried out with the filtrate fraction whereas wash was used for inoculum preparation. All experiments were performed in duplicates, and the average values with standard deviations are presented.

\subsection{Inoculum preparation and LA fermentation by B. coagulans NCIM 5648}

The glucose-rich filtrates obtained after hydrolysis were valorized LA using a thermophilic bacterium B. coagulans NCIM 5648. The pre-seed and seed cultures were prepared in the modified CM5 medium with wash samples as a carbon source (Nalawade et al., 2020). After $8 \mathrm{~h}$, the culture was centrifuged at $5752 \mathrm{~g}$ to remove the residual sugars and LA formed from the actively growing cells of $B$. coagulans. The centrifuged cells were resuspended in physiological saline to achieve a dense inoculum, and optical density (OD) was measured at $600 \mathrm{~nm}$. The LA production medium was prepared in the similar way as described in the preceding lines except that the carbon source was the "glucose-rich filtrate. It was fortified with $\left(\mathrm{gL}^{-1}\right) \mathrm{Na}_{2} \mathrm{HPO}_{4}-2.17 ; \mathrm{KH}_{2} \mathrm{PO}_{4}-0.26 ;\left(\mathrm{NH}_{4}\right)_{2} \mathrm{SO}_{4}-2 ; \mathrm{MgCl}_{2}-0.2 ; \mathrm{CaCl}_{2}-0.025$, yeast extract- 10 and Bromo-cresol purple $-50 \mathrm{mg}$ with initial $\mathrm{pH}$ being $7.2 \pm 0.2$. Fermentation was initiated by adding $2.5 \mathrm{ml}(70 \mathrm{mg})$ of an active and highly dense inoculum $\left(\mathrm{OD}_{600 \mathrm{~nm}} 82.2 \pm 0.47\right)$ in $100 \mathrm{ml}$ medium, and $\mathrm{pH}$ drop was monitored visually by change in dye-color (violet to yellow). The $\mathrm{pH}$ was restored to $7.0 \pm 0.2$ using $8 \mathrm{~N} \mathrm{NaOH}$ intermittently. 
All the experiments were performed in duplicates. Samples were withdrawn periodically and processed for HPLC determination of residual glucose and xylose with the simultaneous production of LA. Metabolites other than LA were also qualitatively detected if present in traces and quantified if emerged as other primary products other than LA.

\subsection{HPLC determination of sugars and fermentation products}

All the sugars (glucose, xylose, cellobiose, arabinose, fructose, sucrose) and possible fermentation products (lactic acid, succinic acid, acetic acid, 2,3 butanediol, ethanol, xylitol) anticipated to be generated during SHF were analyzed by HPLC system (Shimadzu make) equipped with Aminex HPX-87H (Bio-Rad, California, USA) column coupled with refractive index detector (RID-10A; Shimadzu Corporation Japan). The analysis was done at $55^{\circ} \mathrm{C}$ under isocratic conditions with $5 \mathrm{mM} \mathrm{H}_{2} \mathrm{SO}_{4}$ as the mobile phase at a flow rate of $0.55 \mathrm{~mL}$ $\min ^{-1}$ with an injection volume of $20 \mu \mathrm{L}$. Based on the retention time and calibration curves (0.2-1.0 $\left.\mathrm{mg} \mathrm{mL}^{-1}\right)$ using standards, all the sugars and metabolites were determined both qualitatively and quantitatively. The optical purity of LA being an "L" isomer was already confirmed through our earlier study (Nalawade et al., 2020) using chiral column. The glucose productivity during enzymatic saccharification was calculated by dividing the concentration of glucose obtained in the filtrate fraction with the time of hydrolysis and expressed as $\mathrm{g} \mathrm{L}^{-1} \mathrm{~h}^{-1}$.

\section{Results and Discussion}

\subsection{HSES of alkali pretreated SCB}

In any second generation or LCB-based biorefinery, saccharification represents the ratelimiting step. The time course studies revealed that the cellulose saccharification efficiency was $20.99 \pm 1.15 \%$ and $64.62 \pm 2.23 \%$ respectively in $8 \mathrm{~h}$ and $16 \mathrm{~h}$. With $85.7 \%$ efficiency, it peaked in $24 \mathrm{~h}$ and attained saturation when hydrolysis was continued further for $48 \mathrm{~h}$ (Fig $\mathrm{S} 1)$. However, in the case of xylan, $16 \%$ improved xylose yields were seen when hydrolysis was extended from $16 \mathrm{~h}$ to $48 \mathrm{~h}$. A target of $>100 \mathrm{~g} \mathrm{~L}^{-1}$ of glucose in the filtrate fraction was achieved in the first $24 \mathrm{~h}$ only (Fig 2) with $>30 \mathrm{~g} \mathrm{~L}^{-1}$ xylose as well. Besides glucose and xylose, acetic acid, arabinose and cellobiose were also detected qualitatively by HPLC but their concentrations were far below detectable limit.

Further water washing extracted the adhered sugars, which remained adsorbed to the residual biomass. The high standard deviation observed in Fig 2 could be attributed to different volumes of filtrates and washes obtained, which was nullified when total sugar released was estimated on a weight basis, as shown in Table S1 


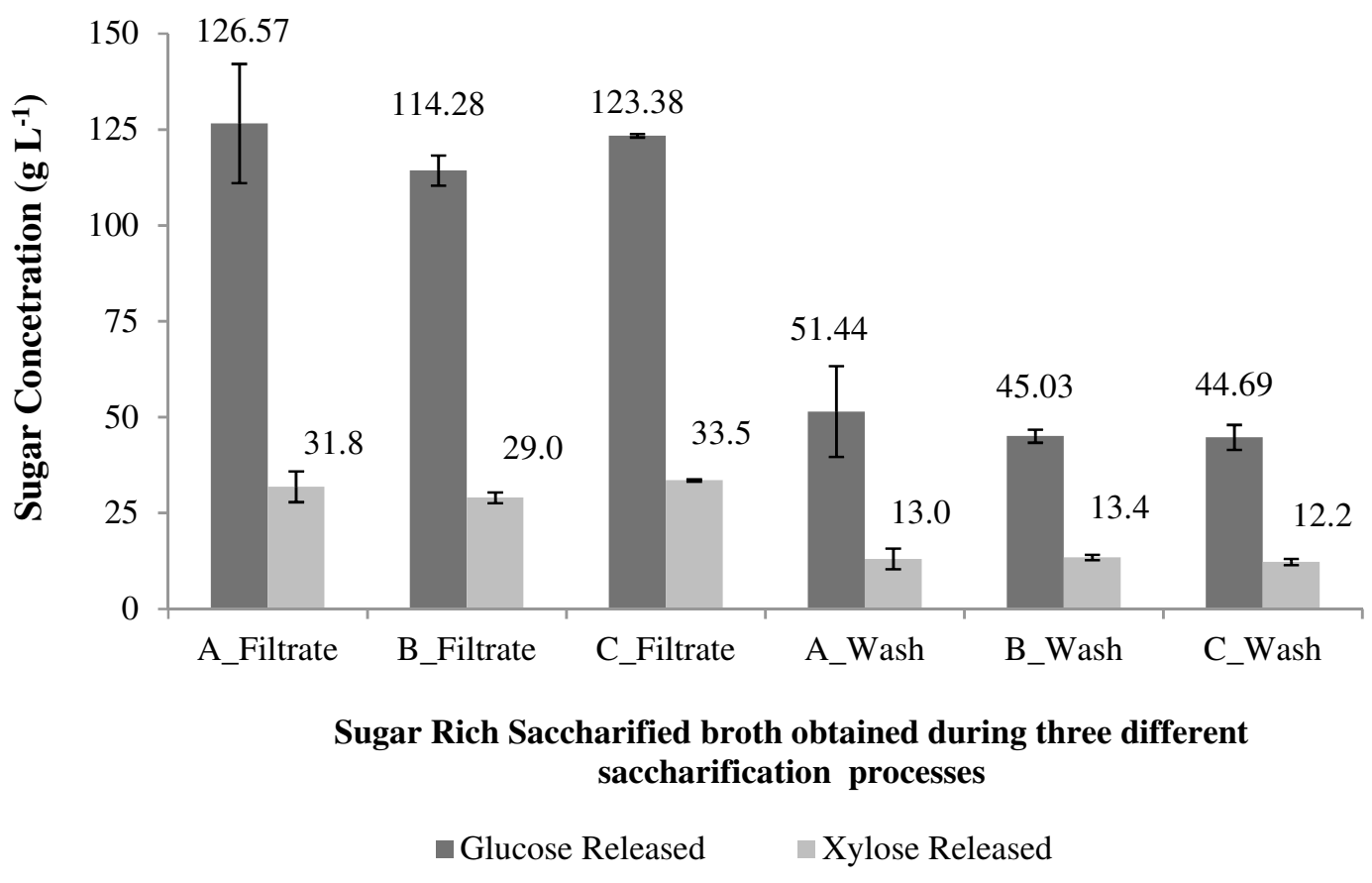

Fig. 2 Sugars (glucose and xylose) released during Cellic CTec2 mediated alkali pretreated sugarcane bagasse hydrolysis as seen in wash and filtrates using three different saccharification processes

Irrespective of the strategy employed for terminating saccharification, $\geq 80 \%$ and $75 \%$ cellulose and xylan hydrolysis was achieved respectively, as shown in Table S1. In the present study when the glucose-rich broth was removed from the residual biomass as in Process B to circumvent the problem of product inhibition, the enzyme bound to the bagasse could not contribute to a higher release of sugars. The low performance of the adsorbed Cellic CTec2 may be due to enzyme deactivation (by soluble, insoluble lignin and biomassderived inhibitors) or inhibition by the unrecovered sugars (Hodge et al., 2008; Puri et al., 2013).

During our previous studies, increasing the substrate loading from 12.5 to $20 \%$ showed a sharp decline in cellulose hydrolysis from $77 \%$ to $68 \%$ (Nalawade et al., 2020). Two-step substrate feeding regime (9+9) with a gap of one hour was able to overcome the drawbacks successfully. Considering Process A, a nearly two-fold increase in glucose concentration was observed in the filtrate fraction, and its productivity improved remarkably from 2.65 to $5.27 \mathrm{~g}$ $\mathrm{L}^{-1} \mathrm{~h}^{-1}$ (Nalawade et al., 2020). Thus, this improved method of feeding favoured high substrate loading without comprising on glucose yields and productivity. The results also indicated that the glucose accumulation of $>120 \mathrm{~g} \mathrm{~L}^{-1}$ severely impaired the rate of hydrolysis. The impedance in sugar release could be attributed to end-product inhibition of Cellic CTec2 
and its successor CTec3 as discussed earlier (Hseih et al., 2014; da Silva et al., 2016). Therefore, further increasing the duration of hydrolysis from 24h (Process A) to 48h (Process C) did not enhance the glucose yields and saccharification efficiency was constant $(\sim 83 \%)$ in both the cases. A similar observation was made during fed-batch hydrolysis of $15 \%$ corn stover, where cellulose hydrolysis improved from 76.4 to $76.9 \%$ when residence time of Cellic CTec2 was increased from $72 \mathrm{~h}$ to $120 \mathrm{~h}$ (Geng et al., 2015). Kadhum et al. also noticed a marginal improvement in glucose release $\left(149.1\right.$ to $\left.151.6 \mathrm{~g} \mathrm{~L}^{-1}\right)$ when the Cellic CTec2 mediated batch hydrolysis of $30 \%$ pretreated wheat straw was extended from 48 to $96 \mathrm{~h}$ (2019).

The present results of achieving glucose concentration of $126.57 \pm 4.03 \mathrm{~g} \mathrm{~L}^{-1}$ (filtrate fraction) and $85.7 \pm 4.8 \%$ cellulose hydrolysis in merely $24 \mathrm{~h}$ by adopting Process $\mathrm{A}$ is far superior to the finding of Liu et al. (2020). They chose fed-batch strategy for the Cellic CTec2 mediated hydrolysis of $30 \%$ alkali pretreated SCB and obtained $86.11 \mathrm{~g} \mathrm{~L}^{-1}$ glucose after $96 \mathrm{~h}$. Earlier, Gao et al. also could get $129.5 \mathrm{~g} \mathrm{~L}^{-1}$ of glucose in $120 \mathrm{~h}$ when they opted for fed-batch hydrolysis of alkali pretreated SCB with Cellic CTec2 enzyme (2014). Even Ramos et al. attained $69.2 \%$ cellulose hydrolysis with Cellic CTec2 in a batch process with $20 \%$ solids after $72 \mathrm{~h}$ with $76.8 \mathrm{~g} \mathrm{~L}^{-1}$ glucose concentration (2015).

Table 1 highlights the glucose concentration and productivity attained by different researchers during HSES of SCB, pretreated by different strategies. 
Table 1: Comparison of enzymatic saccharification of pretreated SCB at high-solids in different studies

\begin{tabular}{|c|c|c|c|c|c|c|c|c|}
\hline $\begin{array}{c}\text { Type of } \\
\text { Pretreatment }\end{array}$ & $\begin{array}{c}\text { Type of } \\
\text { hydrolysis }\end{array}$ & Total Solid Loading (w/v) & $\begin{array}{l}\text { Cellulase and accessory } \\
\text { enzymes used }\end{array}$ & $\begin{array}{c}\text { Time } \\
\text { (h) }\end{array}$ & $\begin{array}{c}\text { Sugar } \\
\text { released } \\
\left(\mathrm{g} \mathrm{L}^{-1}\right) \\
\end{array}$ & $\begin{array}{c}\% \\
\text { cellulose } \\
\text { hydrolysis }\end{array}$ & $\begin{array}{c}\text { Glucose } \\
\text { productivity } \\
\left(\mathrm{g} \mathrm{L}^{-1} \mathbf{h}^{-1}\right) \\
\end{array}$ & Reference \\
\hline Alkali & Fed Batch & $\begin{array}{c}33 \%(12 \% \text { initial followed by } \\
7 \% \text { after every } 6 \mathrm{~h} \text { till } 24 \mathrm{~h})\end{array}$ & $\begin{array}{c}\text { Cellic CTec2 @ } 15.82 \\
\text { FPU/g glucan }\end{array}$ & 120 & $\begin{array}{l}\text { glucose: } 129.5 \\
\text { xylose: } 56.03\end{array}$ & 60 & 1.07 & $\begin{array}{l}\text { Gao et al, } \\
2014\end{array}$ \\
\hline $\begin{array}{l}\text { Alkali and } \\
\text { glycerol }\end{array}$ & Fed batch & $\begin{array}{c}20 \% \text { ( } 8 \% \text { initial followed by } \\
4 \% \text { after every } 6 \mathrm{~h} \text { till } 18 \mathrm{~h}) \\
\text { Additives: } 40 \mathrm{mg} / \mathrm{g} \text { Tween } 80 \text {, } \\
10 \mathrm{mg} / \mathrm{g} \text { tea saponin }+20 \mathrm{mg} / \mathrm{g} \\
\text { BSA }\end{array}$ & $\begin{array}{c}\text { Cellic CTec2 @ } 5.26 \\
\text { FPU/g glucan Accessory } \\
\text { enzymes: } 2.4 \mathrm{mg} / \mathrm{g} \text { endo- } \\
\text { xylanase and } 1 \mathrm{mg} / \mathrm{g} \text { AA9 }\end{array}$ & 72 & $\begin{array}{l}\text { glucose: } 105 \\
\text { xylose: } 51\end{array}$ & 83 & 1.45 & $\begin{array}{l}\text { Mukasekuru } \\
\text { et al., } 2018\end{array}$ \\
\hline Alkali & Fed batch & $\begin{array}{l}22 \% \text { (10\% initial followed by } 5, \\
4 \text { and } 3 \% \text { after } 8,12 \text { and } 16 \mathrm{~h}) ; \\
\text { Additives: Whey protein }-25 \mathrm{mg} \\
+ \text { Tween } 80-40 \mathrm{mg}+ \\
\text { sophorolipid }-25 \mathrm{mg}+\text { calcium } \\
\text { lignosulfonate }-10 \mathrm{mg}\end{array}$ & $\begin{array}{c}\text { Cellic CTec3 @ } 11.54 \\
\text { mg/g glucan }+150 \mathrm{U} \\
\text { hemicellulase/g dry matter } \\
\text { and } 60 \mathrm{mg} \beta \text {-glucosidase/g } \\
\text { dry matter }\end{array}$ & 72 & $\begin{array}{l}\text { glucose: } 127 \\
\text { xylose: } 44\end{array}$ & 80 & 1.76 & Xu et al, 2019 \\
\hline $\begin{array}{c}\mathrm{H}_{3} \mathrm{PO}_{4} \\
\text { impregnated } \\
\text { steam-treated }\end{array}$ & Batch & $20 \%$ & $\begin{array}{c}\text { Cellic CTec2@8.26 } \\
\text { FPU/g glucan }\end{array}$ & 72 & glucose: 76.8 & 69.2 & 1.06 & $\begin{array}{l}\text { Ramos et al., } \\
2015\end{array}$ \\
\hline Hydrothermal & Batch & $20 \%$ & $\begin{array}{c}\text { Cellic CTec2 @ 20FPU/g } \\
\text { glucan }\end{array}$ & 72 & - & 69 & & $\begin{array}{c}\text { da Silva et al., } \\
2016\end{array}$ \\
\hline Steam & Batch & $20 \%$ & $\begin{array}{c}\text { Cellic CTec3@38.6 } \\
\text { FPU/g glucan + Cellic } \\
\text { HTec3 }\end{array}$ & 72 & glucose: 120 & - & 1.66 & $\begin{array}{l}\text { Fockink et al., } \\
2017\end{array}$ \\
\hline Alkali & Batch & $30 \%$ & $\begin{array}{l}\text { Cellic CTec2 @ } 16.61 \\
\text { FPU/g glucan }\end{array}$ & 96 & $\begin{array}{l}\text { glucose: } 86.1 \\
\text { xylose: } 36.6\end{array}$ & 76.4 & 0.89 & $\begin{array}{l}\text { Liu } \text { et al., } \\
2020\end{array}$ \\
\hline Hydrothermal & Batch & $20 \%$ & $\begin{array}{c}\text { Cellic CTec2 @ } 16.27 \text { mg } \\
\text { protein /g glucan }\end{array}$ & 144 & glucose: 95.37 & 70.27 & 0.66 & $\begin{array}{l}\text { Godoy et al., } \\
2019\end{array}$ \\
\hline Acid -alkali & Batch & $20 \%$ & $\begin{array}{l}\text { Cellic CTec2 @ } 13.95 \mathrm{mg} \\
\text { protein /g glucan }\end{array}$ & 144 & glucose: 115.5 & 73 & 0.80 & $\begin{array}{l}\text { Godoy et al., } \\
2019\end{array}$ \\
\hline Alkali & $\begin{array}{c}\text { Batch } \\
\text { Process A }\end{array}$ & $\begin{array}{l}\text { 18\% ; Additive: PEG } 6000 \\
\quad(0.2 \mathrm{~g} / \mathrm{g} \text { AISL content })\end{array}$ & $\begin{array}{c}\text { Cellic CTec2 @ 25mg } \\
\text { protein/g glucan }\end{array}$ & 24 & $\begin{array}{l}\text { glucose: } 126.6 \\
\text { xylose: } 31.8 \\
\text { (Filtrate) } \\
\end{array}$ & 85.7 & $5.27^{\#}$ & This work \\
\hline Alkali & $\begin{array}{c}\text { Batch } \\
\text { Process C }\end{array}$ & $\begin{array}{l}\text { 18\% ; Additive: } \text { PEG } 6000 \\
\quad(0.2 \mathrm{~g} / \mathrm{g} \text { AISL content })\end{array}$ & $\begin{array}{c}\text { Cellic CTec2 @ 25mg } \\
\text { protein/g glucan }\end{array}$ & 48 & $\begin{array}{l}\text { glucose: } 123.4 \\
\text { xylose: } 33.5 \\
\text { (Filtrate) }\end{array}$ & 83.4 & $2.57^{\#}$ & This work \\
\hline
\end{tabular}

\# refers to glucose productivity in the supernatant fraction excluding wash 
Based on the obtained results, the authors feel that extending the time of hydrolysis beyond 24h was futile and unprofitable. Glucose productivity, in particular, decreased from 5.27 to $2.57 \mathrm{~g} \mathrm{~L}^{-1} \mathrm{~h}^{-1}$, when the duration was extended to $48 \mathrm{~h}$ (Fig.3). This result is in concurrence with the findings of $\mathrm{Xu}$ et al., wherein stretching the Cellic CTec3 mediated hydrolysis of alkali pretreated SCB from $48 \mathrm{~h}$ to $72 \mathrm{~h}$ decreased the productivity of glucose by $30 \%$ (2019). If the results of the present study are extrapolated to one kg biomass (Figure 3), the minimum sugar yield obtained after pretreatment and saccharification correspond to $492 \pm 2.71 \mathrm{~g} / \mathrm{kg}$ SCB. These yields are far superior to our earlier results (Nalawade et al., 2020) and cross the threshold benchmark of $400 \mathrm{~g} / \mathrm{kg}$ biomass deciphered by Mark et al. for economically beneficial and favourable production of the biofuels (2020).



Fig. 3 Overall schematics of sugars flow during pretreatment and saccharification from one kg raw sugarcane bagasse based on the results of the present study and sugar productivities from different saccharification processes. 
The present study shows that even shorter duration of HSES can generate concentrated sugar solution with uncompromised productivities. However, an appropriate selection of pretreatment and saccharification strategy is imperative. Pretreatment methods which lead to delignification often tend to reduce biomass recalcitrance and facilitate high digestibility by cellulases (Nguyen et al., 2017; Chi et al., 2019). Considering saccharification aspect, there is a strong need to break the traditional approach of loading new generation cellulase cocktails like their earlier versions. Also, their true hydrolytic potential should be harnessed with an entirely new perspective. The authors are of the view that longer duration with these enzymes is only recommended when loadings are extremely low (5-7.5 FPU or 7.5-10 mg protein/g cellulose content). There is immense scope for improving the saccharification process by identifying the maximum tolerance limit of these generation enzyme cocktails for their end products and inhibitors. Later these features can be correlated with the type of pretreatment rather than solely concentrating on developing newer pretreatment strategies.

Even during fed-batch hydrolysis, feeding regimes should be restricted to $8 \mathrm{~h}$ as it represents the onset of the exponential phase of cellulose liquefaction. Once the hydrolysis enters this phase, the sugars released tend to impede the hydrolysis of fresh fed substrate, reducing the overall efficiency of the process. Moreover, substrate loading beyond $25 \%$ needs to be forbidden as by loading beyond this threshold value researchers are compelled to extend hydrolysis time for complete extraction of valuable fermentable sugars from biomass.

\subsection{Valorization of released sugars to LA using fermentative B. coagulans NCIM 5648}

The time course profile of glucose consumption and LA production by B. coagulans under the $\mathrm{pH}$-stat condition at $50^{\circ} \mathrm{C}$ and $150 \mathrm{rpm}$ are shown in Figure 4. Besides "L" isomer of LA as the primary product of fermentation, succinic acid and 2,3 BDO were also detected in HPLC after $12 \mathrm{~h}$, with their cumulative concentration's not exceeding beyond $1 \%$. 



Fig. 4 Time course profile of glucose \& xylose consumption and LA production by B. coagulans under $\mathrm{pH}$ stat conditions at $50^{\circ} \mathrm{C}$ and $150 \mathrm{rpm}$ in filtrates obtained by (a) Process A (b) Process B (c) Process C. 
As reported earlier, glucose was the preferred carbon source and xylose invariably remained unutilized. After $24 \mathrm{~h}$ fermentation, 71, 72.7 and $71.6 \mathrm{~g} \mathrm{~L}^{-1}$ of LA were produced from the filtrates obtained by Process A, B and C, respectively. Intermittent opening of flasks for $\mathrm{pH}$ restoration disfavored maintenance of complete anaerobic conditions. As a result, $20 \%$ glucose was diverted towards biomass accumulation which rose significantly ( $\sim 9$ fold). An LA productivity of $\geq 2.88 \mathrm{~g} \mathrm{~L}^{-1} \mathrm{~h}^{-1}$ compared to $1.75 \mathrm{gL}^{-1} \mathrm{~h}^{-1}$ in our previous study confirmed that $B$. coagulans mediated fermentation was primarily dependent on the initial glucose concentration and undetectable inhibitors produced during SCB hydrolysis at highsolids had no impact on the performance of the bacterium (Nalawade et al., 2020). These results are highly encouraging when compared to the duration taken and LA yields by various researchers for the production of $\mathrm{L}(+)$ lactic acid from different lignocellulosic feedstocks using SSF approach (Table 2). 
Table 2: Summary of HSES carried out with different types of pretreated lignocellulosic biomass and subsequent LA fermentation

\begin{tabular}{|c|c|c|c|c|c|c|}
\hline $\begin{array}{l}\text { Biomass and } \\
\text { pretreatment }\end{array}$ & $\begin{array}{l}\text { Hydrolysis and } \\
\text { Fermentation }\end{array}$ & $\begin{array}{c}\text { Conditions during Enzymatic saccharification and } \\
\text { fermentation }\end{array}$ & $\begin{array}{c}\text { Total Duration } \\
(\mathbf{h})\end{array}$ & $\begin{array}{l}\text { LA formed } \\
\left(\mathrm{g} \mathrm{L}^{-1}\right)\end{array}$ & LA yield & Reference \\
\hline $\begin{array}{c}\mathrm{NH}_{3}-\mathrm{H}_{2} \mathrm{O}_{2} \text {-pretreated } \\
\text { corncob }\end{array}$ & Fed Batch SSCF ${ }^{\$}$ & $\begin{array}{l}\text { Total Solid Loading: } 16 \% \text { with initial loading } 8 \% \text { and } \\
4 \% \text { loading after } 18 \mathrm{~h} \text { and } 24 \mathrm{~h} \\
\text { Enzyme: Cellic CTec2 @ } 75 \text { FPU/g glucan } \\
\text { Conditions: pH stat-6.0; Temp-50 }{ }^{\circ} \mathrm{C} ; 100 \mathrm{rpm} \\
\text { Organism used: Bacillus coagulans LA } 204 \\
\end{array}$ & 90 & 118.6 & $\begin{array}{l}0.74 \mathrm{~g} / \mathrm{g} \text { of } \\
\text { total stover } \\
\text { (glucose and } \\
\text { xylose) }\end{array}$ & $\begin{array}{l}\text { Zhang et al., } \\
\qquad 2016\end{array}$ \\
\hline $\begin{array}{l}\text { Dilute acid pretreated } \\
\text { corn stover }\end{array}$ & Batch SSF* & $\begin{array}{l}\text { Total Solid Loading: } 27 \% \text { in 50L bioreactor } \\
\text { Enzyme: Accellerase } 1000 \text { @ } 15 \mathrm{FPU} / \mathrm{g} \text { substrate } \\
\text { Conditions: pH stat-5.5; Temp-48 }{ }^{\circ} \mathrm{C} ; 150 \mathrm{rpm} \\
\text { Organism used: Pediococcus acidilactici DQ2 }\end{array}$ & $\begin{array}{c}8^{a}+96 \\
(104)\end{array}$ & 101.9 & $\begin{array}{l}0.77 \mathrm{~g} / \mathrm{g} \\
\text { glucose } \\
\text { consumed }\end{array}$ & $\begin{array}{l}\text { Zhao et al., } \\
\quad 2013\end{array}$ \\
\hline $\begin{array}{l}\mathrm{NaOH} \text { pretreated } \\
\text { sweet sorghum } \\
\text { bagasse }(\mathrm{SSB})\end{array}$ & Batch SSF* & $\begin{array}{c}\text { Total Solid Loading: } 15 \% \\
\text { Enzyme: Cellulase from Tianfeng Bioengineering } \\
\text { Corporation, China @ 48.38 FPU/g glucan } \\
\text { Conditions: pH stat-5.6; Temp-50 } \\
\text { Organism used: Bacillus coagulans LA1507 } \\
\end{array}$ & $\sim 70$ & 74 & $\begin{array}{l}0.59 \mathrm{~g} / \mathrm{g} \\
\mathrm{SSB}\end{array}$ & $\begin{array}{l}\text { Wang et al., } \\
2016\end{array}$ \\
\hline $\begin{array}{l}\text { Dilute acid pretreated } \\
\text { corn stover }\end{array}$ & Batch SSF* & $\begin{array}{c}\text { Total Solid Loading: } 30 \% \\
\text { Enzyme: Youtell \#6 @ } 28 \text { mg protein/g glucan content } \\
\text { Conditions: pH stat-5.5; Temp- } 45^{\circ} \mathrm{C} ; 150 \mathrm{rpm} \\
\text { Organism used: Pediococcus acidilactici TY } 112 \\
\end{array}$ & $\begin{array}{c}6^{a}+72 \\
(78)\end{array}$ & 87.8 & $\begin{array}{l}0.62 \mathrm{~g} / \mathrm{g} \\
\text { glucose } \\
\text { consumed }\end{array}$ & Liu et al., 2015 \\
\hline $\begin{array}{l}\text { Dry acid pretreated } \\
\text { and bio-detoxified } \\
\text { corn stover }\end{array}$ & $\mathrm{SSCF}^{\$}$ & $\begin{array}{l}\text { Total Solid Loading: } 30 \% \text { Solids containing } 33.3 \% \\
\text { cellulose, } 3.35 \% \text { xylan and } 11.5 \% \text { xylose as principal } \\
\text { components and } 12.6 \% \text { other soluble sugars. } \\
\text { Enzyme: Cellic CTec2 @ } 15 \mathrm{mg} \text { protein/g glucan } \\
\text { Conditions: pH stat-5.5; Temp- } 42^{\circ} \mathrm{C} ; 150 \mathrm{rpm} \\
\text { Organism used: Pediococcus acidilactici ZY271 }\end{array}$ & $\begin{array}{c}6^{a}+72 \\
(78)\end{array}$ & 130.2 & & Han et al., 2018 \\
\hline $\begin{array}{l}\text { Beechwood } \\
\text { organosolv } \\
\text { hydrolysate }\end{array}$ & $\begin{array}{l}\text { Fermentation of } \\
\text { hydrolysate }\end{array}$ & $\begin{array}{c}\text { Prehydrolysate containing }(\mathrm{g} / \mathrm{L}) \text { nearly } 82.25 \text { glucose; } \\
21.81 \text { xylose and } 27.23 \text { cellobiose } \\
\text { Conditions: pH stat- } 6.0 ; \text { Temp- } 52^{\circ} \mathrm{C} ; \\
\text { Organism used: Bacillus coagulans } \text { DSM } 2314 \\
\end{array}$ & 30 & $79.4 \pm 2.1$ & $\begin{array}{l}0.6 \mathrm{~g} / \mathrm{g} \\
\text { xylose and } \\
\text { glucose } \\
\text { consumed }\end{array}$ & $\begin{array}{c}\text { Glaser G and } \\
\text { Venus J., } 2018\end{array}$ \\
\hline $\begin{array}{l}\mathrm{NaOH} \text { pretreated } \\
\text { corn stover }\end{array}$ & Fed Batch SSCF ${ }^{\$}$ & $\begin{array}{l}\text { Total Solid Loading: } 14.4 \% \text { with initial loading } 8 \% \text { and } \\
\text { rest within } 18-20 \mathrm{~h} \\
\text { Enzyme: Cellic CTec2 @ 53.6 FPU/g glucan content } \\
\text { Conditions: pH stat-6.0; Temp-50 } 5 \text {; } 100 \mathrm{rpm} \\
\text { Organism used: Bacillus coagulans LA } 204 \\
\end{array}$ & 60 & 97.59 & $\begin{array}{l}0.68 \mathrm{~g} / \mathrm{g} \text { of } \\
\text { total stover } \\
\text { (glucose and } \\
\text { xylose) }\end{array}$ & Hu et al., 2015 \\
\hline
\end{tabular}




\begin{tabular}{|c|c|c|c|c|c|c|}
\hline $\begin{array}{l}\mathrm{NaOH} \text { pretreated } \\
\text { sugarcane bagasse }\end{array}$ & Batch $\mathrm{SHF}^{\#}$ & $\begin{array}{c}\text { Total Solid Loading: } 18 \% \\
\text { Enzyme: Cellic CTec2 @ 25mg protein/g glucan } \\
\text { Conditions: pH stat-7.0; Temp-50 } \mathrm{C} ; 150 \mathrm{rpm} \\
\text { Organism used: Bacillus coagulans NCIM } 5648\end{array}$ & $\begin{array}{c}24^{\mathrm{b}}+24 \\
\quad(48)\end{array}$ & $69.2 \pm 2.5$ & $\begin{array}{l}0.759 \mathrm{~g} / \mathrm{g} \\
\text { glucose } \\
\text { consumed }\end{array}$ & This study \\
\hline
\end{tabular}

*SSF refers to simultaneous saccharification and fermentation; SHF" refers to Separate hydrolysis and fermentation; SSCF ${ }^{\$}$ refers to simultaneous saccharification and co-

fermentation of two sugars namely glucose and xylose; ${ }^{\mathrm{a}}$ refers to pre-hydrolysis without fermenting microbe; ${ }^{\text {b }}$ refers to enzymatic saccharification in batch mode 
This investigation gains more significance in the light of recent findings by Kadhum et al., where the targeted product was ethanol (2019). During their study, SHF was compared to SSF with 30\% dilute acid pretreated wheat straw using Cellic CTec2. They inferred that lower processing times during saccharification and fermentation not only had a lower environmental impact (during sensitivity analysis) but it also played an instrumental role on Return on Investment (ROI). Even Müller et al. also reported 26-32\% more LA yields in SHF set up as compared to SSF while carrying out hydrolysis of $10 \%$ steam-exploded birch with Cellic CTec2 in combination with lactic acid bacteria (2017).

With the existing productivities of glucose and LA obtained in the present SHF study, the authors believe that sugar industries can intervene and collaborate with research groups working on similar lines to evaluate the proposed scheme for efficient SCB valorization and process integration. Holistic utilization of entire SCB is envisaged by feeding the dewatered lignin-rich black liquor (obtained after alkali pretreatment) to the boilers for steam generation. A significant improvement in the LA yields and productivity is foreseen; when the same experiments are shifted from shake flasks to bioreactor wherein the microaerophilic environment, including temperature and $\mathrm{pH}$ conditions, can be controlled tightly. Xylose which presently remains unutilized can be removed by sequential hydrolysis with acid or hydrothermal treatment followed by alkali. We envisage to go for process integration wherein xylose can be transformed to valorized products like succinic acid and xylitol, as demonstrated by our collaborators (Prabhu et al., 2020a; Prabhu et al., 2020b). In the future, we target to reduce the enzyme dosage by at least 1.5 times by optimizing feeding strategy, using in-house developed enzymes in combination and working towards process conditions or working towards enzyme recycling and reuse.

\section{Conclusion}

The present study showed that the expeditious production of glucose was possible from $18 \%$ alkali pretreated SCB, with unprecedented glucose titers $\left(\sim 126 \mathrm{~g} \mathrm{~L}^{-1}\right)$ in $24 \mathrm{~h}$ and its productivity being $5.27 \mathrm{~g} \mathrm{~L}^{-1} \mathrm{~h}^{-1}$. Its direct valorization led to the production of $69.2 \pm 2.5 \mathrm{~g} \mathrm{~L}^{-}$ ${ }^{1} \mathrm{~L}(+)$ lactic acid within $24 \mathrm{~h}$ with LA productivity being $2.88 \mathrm{~g} \mathrm{~L}^{-1} \mathrm{~h}^{-1}$. This study proves that there is an enormous scope to maximize and exploit the efficiency of new generation cellulases, thereby sustainably producing sugar syrups from LCB. An environmentally benign process is driven by these enzymes for cellulose hydrolysis, which can be transformed into any commercially viable product, LA being a representative in the present case. 


\section{Acknowledgements}

This research was financially supported by the Department of Biotechnology (DBT, India) under the Indo-UK Industrial Waste Challenge 2017 project, with grant number being GAP 3513. Authors would also like to acknowledge our industrial partner, Dhampur Sugar Mills, for providing us sugarcane bagasse. The authors are thankful to Dr Anjan Ray, Director CSIR-Indian Institute of Petroleum, for providing necessary facilities to complete this work and his constant motivation.

\section{References}

Baral, P., Jain, L., Kurmi, A.K. Kumar, V., Agrawal, D. 2020. Augmented hydrolysis of acid pretreated sugarcane bagasse by PEG 6000 addition: a case study of Cellic CTec2 with recycling and reuse, Bioproc. Biosys. Engg. 43, 473-482. https://doi.org/10.1007/s00449019-02241-3.

Bradford, M.M., 1976. A rapid and sensitive method for the quantitation of microgram quantities of protein utilizing the principle of protein-dye binding. Anal. Biochem. 72, 248-254. https://doi.org/10.1016/0003-2697(76)90527-3.

Cannella, D., Jørgensen, H., 2013. Do new cellulolytic enzyme preparations affect the industrial strategies for high solids lignocellulosic ethanol production? Biotechnol. Bioengg. 111, 59-68. https://doi.org/10.1002/bit.25098.

Chen, H, Liu, Z., 2016. Enzymatic hydrolysis of lignocellulosic biomass from low to high solids loading. Eng. Life. Sci. 00, 1-11. https://doi.org/10.1002/elsc.201600102.

Chi, X., Liu, C., Bi, Y., Yu, G., Zhang, Y., Wang, Z., Li, B., Cui, Q., 2019. A clean and effective potassium hydroxide pretreatment of corn cob residue for enhancement of enzymatic hydrolysis at high solids loading. RSC Adv. 9, 11558-11566. https://doi.org/10.1039/C9RA01555H

Cubas-Cano, E, González-Fernández, C., Ballesteros, M., Tomás-Pejó, E. 2018. Biotechnological advances in lactic acid production by lactic acid bacteria: lignocellulose as novel substrate. Biofuels. Bioprod. Bioref. 12 (2), 290-303. 10.1002/bbb.1852

da Silva, A.S.A., de Souza, M.F. Ballesteros, I., Manzanares, R., Ballesteros, M., Bon, E.P.S., 2016. High-solids content enzymatic hydrolysis of hydrothermally pretreated sugarcane bagasse using a laboratory-made enzyme blend and commercial preparations. Proc.

Biochem. 51, 1561-1567 https://doi.org/10.1016/j.procbio.2016.07.018

da Silva, A.S.A., Espinheira, R.P., Teixeira, R.S.S., de Souza, M.F., Ferreira-Leitao, V., Bon, E.P.S., 2020. Constraints and advances in high-solids enzymatic hydrolysis of 
lignocellulosic biomass: a critical review. Biotechnol Biofuels. 13, 58. https://doi.org/10.1186/s13068-020-01697-w

Ekwe, E., Morgenstern, I., Tsang, A., Storms, R., Powlowski, J., 2013. Non-hydrolytic cellulose active proteins: research progress and potential applications in biorefineries. Industr. Biotechnol. 9, 123-131. https://doi.org/10.1089/ind.2013.0010

Fockink, D.H., Urio, M.B., Sanchez, J.H., Ramod, L.P., 2017. Enzymatic hydrolysis of steam-treated sugarcane bagasse: effect of enzyme loading and substrate total solids on its fractal kinetic modeling and rheological properties. Energ. Fuels. 31, 6211-6220. https://doi.org/10.1021/acs.energyfuels.7b00818

Gao, Y., Xu, J., Yuan, Z., Zhang, Y., Liu, Y., Liang, C., 2014. Optimization of fed-batch enzymatic hydrolysis from alkali-pretreated sugarcane bagasse for high-concentration sugar production. Bioresour. Technol. 167, 41-45. https://doi.org/10.1016/j.biortech.2014.05.034

Geng, W., Jin, Y., Jameel, H., Park, S., 2015. Strategies to achieve high-solids enzymatic hydrolysis of dilute-acid pretreated corn stover. Bioresour. Technol. 187, 43-48. https://doi.org/10.1016/j.biortech.2015.03.067.

Ghosh, T.K. 1987. Measurement of cellulase activities. Pure \& Appl. Chem. 59, 257-268.

Glaser, R., Venus, J., 2018. Co-fermentation of the main sugar types from a beechwood organosolv hydrolysate by several strains of Bacillus coagulans results in effective lactic acid production. Biotechnol. Rep. 18, e00245. https://doi.org/10.1016/j.btre.2018.e00245

Godoy, C.M., Machado, D.L., Costo, C., 2019. Batch and fed-batch enzymatic hydrolysis of pretreated sugarcane bagasse -Assay and modelling. Fuel. 253, 392-399. https://doi.org/10.1016/j.fuel.2019.05.038

Guragain, Y.N., Wang, D., Vadlani, P.V., 2016. Appropriate biorefining strategies for multiple feedstocks: Critical evaluation for pretreatment methods, and hydrolysis with high solids loading. Renew. Energ. 96, 832-842. . https://doi.org/10.1016/j.renene.2016.04.099

Han, X., Hong, F., Liu, G., Bao, J., 2018. An approach of utilizing water-soluble carbohydrates in lignocellulosic feedstock for promotion of cellulosic L-Lactic acid production. J. Agric. Food. Chem. 66, 10225-10232. https://doi.org/10.1021/acs.jafc.8b03592.

Hodge, D.B., Karim, M.N., Schell, D.J., McMillan, J.D., 2008. Soluble and insoluble solids contributions to high-solids enzymatic hydrolysis of lignocellulose. Bioresour. Technol. 99, 8940-8948. https://doi.org/10.1016/j.biortech.2008.05.015 
Hseih, C.C., Cannella, D., Jørgensen, H., Felby, C., Thygesen, L.G., 2014. Cellulase inhibition by high concentrations of monosaccharides. J. Agric. Food. Chem. 62, 38003805. https://doi.org/10.1021/jf5012962

https://www.indiansugar.com/Statics.aspx. Accessed on $18^{\text {th }}$ June 2020.

Hu, J., Zhang, Z., Lin, Y., Zhao, S., Mei, Y., Liang, Y., Peng, N., 2015. High-titer lactic acid production from $\mathrm{NaOH}-$ pretreated corn stover by Bacillus coagulans LA204 using fedbatch simultaneous saccharification and fermentation under non-sterile condition. Bioresour. Technol. 182: 251-257. http://dx.doi.org/10.1016/j.biortech.2015.02.008 Kadhum, H.J., Mahapatra, D.M., Murthy, G.S., 2019. A comparative account of glucose yields and bioethanol production from separate and simultaneous saccharification and fermentation processes at high solids loading with variable PEG concentration. Bioresour. Technol. 83, 67-75. https://doi.org/10.1016/j.biortech.2019.03.060

Liu, G., Sun, J., Zhang, J., Tu, Y., Bao, J., 2015. High titer L-lactic acid production from corn stover with minimum waste water generation and techno-economic evaluation based on Aspen plus modeling. Bioresour. Technol. 198, 803-810. https://doi.org/10.1016/j.biortech.2015.09.098

Liu, Y., Yu, Q., Xu, J., Yuan, Z., 2020. Evaluation of structural factors affecting high solids enzymatic saccharification of alkali-pretreated sugarcane bagasse. Cellulose, 27, 14411450. https://doi.org/10.1007/s10570-019-02890-3.

Lopes, A.M., Filho, E.X.F., Moreira, L.R.S., 2018. An update on enzymatic cocktails for lignocellulosic breakdown. J. Appl. Microbiol. 125, 632-645. 10.1111/jam.13923

Mandegari, M.A., Farzad, S., Rensburg, E., Görgens, J.F., 2017. Multi-criteria analysis of a biorefinery for co-production of lactic acid and ethanol from sugarcane lignocellulose. Biofuels, Bioprod. Bioref. 11, 971-990. https://doi.org/10.1002/bbb.1801.

Marks, C., König, A., Mitsos, A., Viell, J., 2020. Minimal viable sugar yield of biomass pretreatment. Biofuels. Bioprod. Bioref. 14, 301-314. https://doi.org/10.1002/bbb.2074

Modenbach, A.A., Nokes, S.E., 2013. Enzymatic hydrolysis of biomass at high-solids loadings-A review. Biomass Bioenerg. 56, 526-544. https://doi.org/10.1002/bbb.2074.

Mukasekuru, M.R., Hu, J., Zhao, X., Sun, F.F., Pascal, K., Ren, H., Zhang, Z., 2018. Enhanced high-solids fed batch enzymatic hydrolysis of sugarcane bagasse with accessory enzymes and additives at low cellulase loading. ACS Sustainable Chem Eng. 6, 1278712796. https://doi.org/10.1021/acssuschemeng.8b01972 
Müller, G., Kalyani, D.C., Horn, S.J., 2017. LPMOs in cellulase mixtures affect fermentation strategies for lactic acid production from lignocellulosic biomass. Biotechnol. Bioengg. 114, 552-559. https://doi.org/10.1186/s13068-015-0376-y.

Nalawade, K. Baral, P. Patil, S. Pundir, A. Kurmi, A.K., Konde, K., Patil, S., Agrawal, D., 2020. Evaluation of alternative strategies for generating fermentable sugars from highsolids alkali pretreated sugarcane bagasse and successive valorization to $\mathrm{L}(+)$ lactic acid. Renew. Energ. 157, 708-717. https://doi.org/10.1016/j.renene.2020.05.089

Nguyen, T.Y., Cai, C.M., Kumar, R. Wyman, C.E., 2017. Overcoming factors limiting highsolids fermentation of lignocellulosic biomass to ethanol. PNAS. 114, 11673-11678. https://doi.org/10.1073/pnas.1704652114

Patil, A., 2019. Bagasse would become real problem for sugar industry in next five years: Sanjay Awasthi, https://www.chinimandi.com/bagasse-would-become-real-problem-forsugar-industry-in-next-five-years-sanjay-awasthi/. Accessed on $18^{\text {th }}$ June 2020.

Prabhu, A.A. Ledesma-Amaro, R., Lin, C.S.K, Coulon, F., Thakur, V.K. Kumar, V. 2020 a. Bioproduction of succinic acid from xylose by engineered Yarrowia lipolytica without $\mathrm{pH}$ control. Biotechnol. Biofuels. 13:113. https://doi.org/10.1186/s13068-020-01747-3

Prabhu, A.A. Thomas, D.J., Ledesma-Amaro, R., Leeke, G.A., Medina, A., VerheeckeVaessen, C., Coulon, F., Agrawal, D., Kumar, V. 2020 b. Biovalorization of crude glycerol and xylose into xylitol by oleaginous yeast Yarrowia lipolytica. Microb. Cell Fact. 19: 121. https://doi.org/10.1186/s12934-020-01378-1

Puri, D.J., Heaven, S. Banks, C.J., 2013. Improving the performance of enzymes in hydrolysis of high solids paper pulp derived from MSW., Biotechnol. Biofuels. 6, 107. https://doi.org/10.1186/1754-6834-6-107

Ramos, L.P., da Silva, L., Ballem, A.C., Pitarelo, A.P., Chiarello, L.M. Silveria, M.H.L., 2015. Enzymatic hydrolysis of steam-exploded sugarcane bagasse using high total solids and low enzyme loadings. Bioresour Technol. 175 (2015) 195-202. https://doi.org/10.1016/j.biortech.2014.10.087

Rosales-Calderon, O., Arantes, V., 2019. A review on commercial-scale high-value products that can be produced alongside cellulosic ethanol. Biotechnol. Biofuels. 12:240. https://doi.org/10.1186/s13068-019-1529-1

Sluiter, A., Hames, B., Ruiz, R., Scarlata, C., Sluiter, J., Templeton, D., Crocker, D., 2012. Determination of structural carbohydrates and lignin in biomass. NREL/TP-510-42618.

Sluiter, A., Hames, B., Ruiz, R., Scarlata, C., Sluiter, J., Templeton, D., 2008. Determination of Ash in Biomass. NREL/TP-510-42622. 
Tarraran, L., Mazzoli R. 2018. Alternative strategies for lignocellulose fermentation through Lactic acid bacteria: The state of the art and perspectives. FEMS Microbiol. Lett. 365(15): fny126. doi: 10.1093/femsle/fny126

Vera, I., Hoefnagels, R. Kooij, A., Moretti, C., Junginger, M., 2020. A carbon footprint assessment of multi-output biorefineries with international biomass supply: a case study for the Netherlands. Biofuels. Bioprod. Bioref. 14, 198-224. https://doi.org/10.1002/bbb.2052

Wang, Y., Wang, M., Cai, D., Wnag, B., Wang, Z., Qin, P., Tan, T., 2016. Efficient L-Lactic acid production from sweet sorghum bagasse by open simultaneous saccharification and fermentation. RSC Adv. 6, 35771-35777. . https://doi.org/10.1039/C6RA04538C

Wenger, J., Stern, T., 2019. Reflection on the research on and implementation of biorefinery systems-a systematic literatures review with focus on feedstock. Biofuels. Bioprod. Bioref. 1, 1347-1364. https://doi.org/10.1002/bbb.2021.

Xu, C., Zhang, J., Zhang, Y., Guo, Y., Xu, H., Liang, C., Wang, Z., Xu, J., 2019.

Enhancement of high solids enzymatic hydrolysis efficiency of alkali pretreated sugarcane bagasse at low cellulase dosage by fed-batch strategy based on optimized accessory enzymes and additives. Bioresour. Technol. 292, 121993.

Zhang, Z., Xie, Y., He, X., Li, X., Hu, J., Ruan, Z., Zhao, S., Peng, N., Liang, Y., 2016. Comparison of high-titer lactic acid fermentation from $\mathrm{NaOH}$ and $\mathrm{NH} 3-\mathrm{H} 2 \mathrm{O} 2$-pretreated corncob by Bacillus coagulans using simultaneous saccharification and fermentation. Sci. Rep. 6, 37245. https://doi.org/10.1038/srep37245

Zhao, K., Qiao, Q., Chu, D., Gu, H., Dao, T.H., Zhang, J., Bao, J., 2013. Simultaneous saccharification and high titer lactic acid fermentation of corn stover using newly isolated lactic acid bacterium Pediococcus acidilactici DQ2. Bioresour. Technol. 135, 481-489. https://doi.org/10.1016/j.biortech.2012.09.063 


\section{Figure Captions:}

Fig.1 Schematics of terminating Cellic CTec2 aided saccharification conducted with alkali pretreated sugarcane bagasse

Fig. 2 Sugars (glucose and xylose) released during Cellic CTec2 mediated alkali pretreated sugarcane bagasse hydrolysis as seen in wash and filtrates using three different saccharification processes

Fig. 3 Overall schematics of sugars flow during pretreatment and saccharification from one $\mathrm{kg}$ raw sugarcane bagasse based on the results of the present study and sugar productivities from different saccharification processes.

Fig. 4 Time course profile of glucose $\&$ xylose consumption and LA production by $B$. coagulans under $\mathrm{pH}$ stat conditions at $50^{\circ} \mathrm{C}$ and $150 \mathrm{rpm}$ in filtrates obtained by (a) Process A (b) Process B (c) Process C.

Fig. S1 Cellulose and xylan saccharification efficiency during Cellic CTec2 mediated alkali pretreated sugarcane bagasse hydrolysis at different time points. 


\section{Supplementary information}

Fig S1: Cellulose and xylan saccharification efficiency during Cellic CTec2 mediated alkali pretreated sugarcane bagasse hydrolysis at different time points.

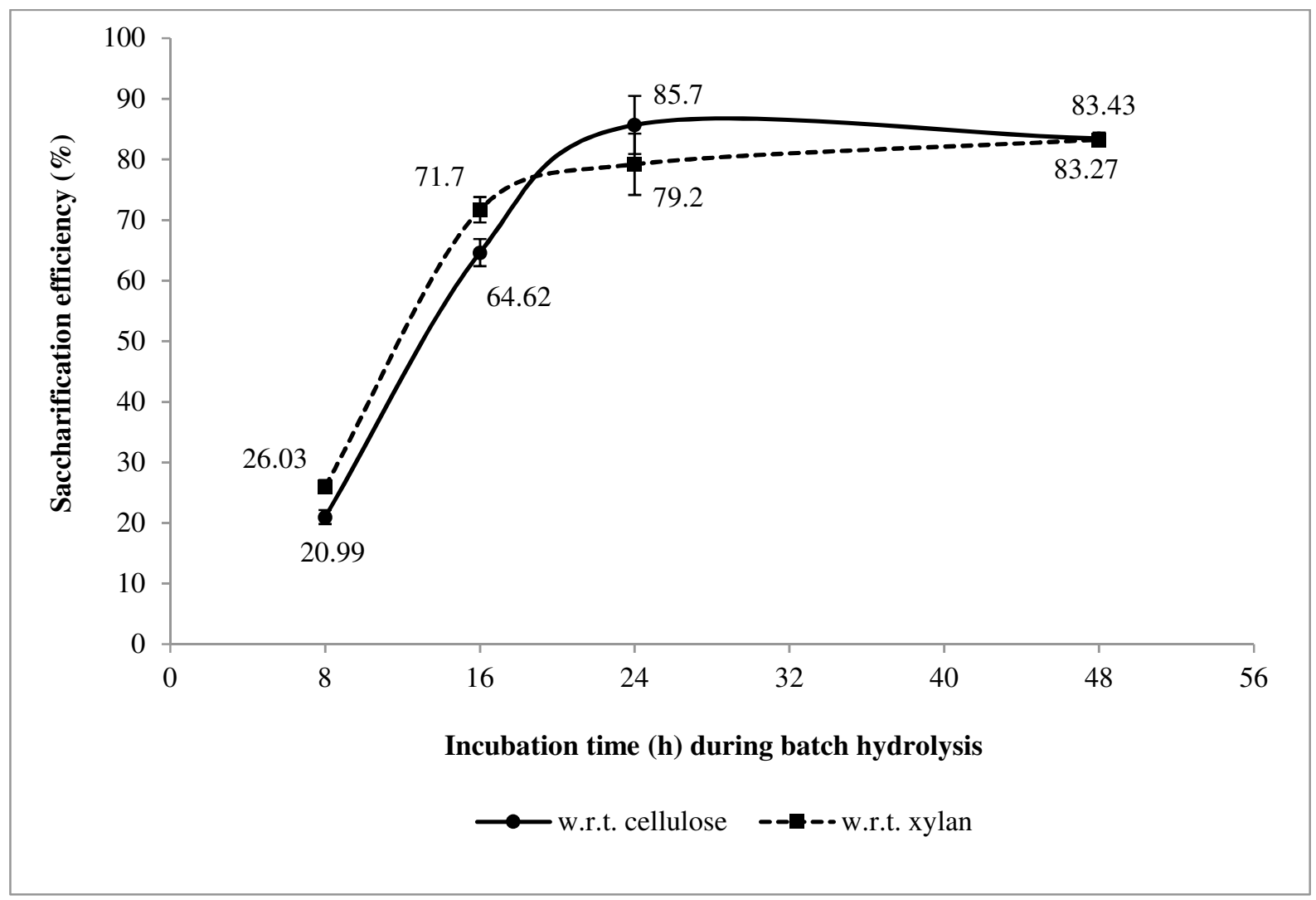

Table S1: Sugars released (g) and saccharification efficiency (\%) from $18 \mathrm{~g}$ alkali pretreated SCB by Cellic CTec 2 at $50^{\circ} \mathrm{C}$ and $\mathrm{pH} 4.5$

\begin{tabular}{ccccc}
\hline Process conditions & \multicolumn{2}{c}{ Total sugars released $(\mathbf{g})$} & \multicolumn{2}{c}{ Saccharification efficiency $(\%)$} \\
\hline & glucose & xylose & w.r.t cellulose & w.r.t. xylan \\
\hline A & $10.91 \pm 0.61$ & $2.75 \pm 0.17$ & $85.69 \pm 4.8$ & $79.21 \pm 5.06$ \\
B & $10.78 \pm 0.70$ & $2.84 \pm 0.22$ & $84.64 \pm 5.5$ & $81.82 \pm 6.36$ \\
C & $10.62 \pm 0.12$ & $2.89 \pm 0.02$ & $83.43 \pm 1.0$ & $83.27 \pm 0.71$ \\
\hline
\end{tabular}

